\title{
The necessity of management in a lake of the Atlantic Forest biodiversity hotspot: nitrogen levels connected to a persistent bloom of Cylindrospermopsis raciborskii
}

\author{
Cleber Cunha Figueredo ${ }^{1 *}$, Gabriela von Rückert ${ }^{2}$ and Alessandra Giani'
}

Received: December 23, 2015

Accepted: March 17, 2016

\begin{abstract}
Conservational studies of the threatened Atlantic Forest biome are frequently restricted to terrestrial ecosystems. We know little about the water bodies, specially considering that this biome covers the third largest system of lakes in Brazil. Some of these lakes are located inside the protected "Rio Doce State Park", but many others are found outside this reserve. These external lakes are seldom studied, but understanding their response to human activities is essential for the conservation and the protection of the lakes inside the Park. We evaluated the effects of degradation in a lake outside the Park, which shows a constant bloom of the toxic invasive cyanobacteria Cylindrospermopsis raciborskii. Phytoplankton, climate and physico-chemical variables were assessed from 2011 to 2013 to evaluate which were the major determinants of the lake dynamics. Despite the seasonal changes, the lake was always eutrophic, and cyanobacteria, transparency and nutrients were the major indicators of water characteristics. The lake seems to be nitrogen-limited and cyanobacteria were negatively correlated with nitrogen levels, since the constantly dominant C. raciborskii is a superior competitor for $\mathrm{N}$. We suggest that the monitoring of nitrogen levels is fundamental to establish management strategies to avoid harmful algae blooms in this Atlantic Forest lake.
\end{abstract}

Keywords: Cylindrospermopsis raciborskii, invasive species, lake conservation, phytoplankton, water deterioration

\section{Introduction}

The Atlantic Forest was one of the largest rainforests of the Americas, with an area of about 150 million ha, but it was reduced to fragments that cover only 11.4 to $16 \%$ of its original area (Ranta et al. 1998; Ribeiro et al. 2009). Due to its high species diversity, endemisms, and because it is threatened by strong anthropogenic pressure, this biome is considered the fourth most important hotspot for biodiversity (Myers et al. 2000). This shows the need of more studies to improve the comprehension of its functioning, which is fundamental for future management and conservation programs. At present, most research developed for the conservation of Atlantic Forest is centered on land environments and terrestrial species, with proportionally far fewer studies on the aquatic ecossystems (Yoshida \& Uieda 2014). Since waterbodies can be affected by events occurring in different parts of the watershed, we could expect that the degradation in the surrounding land would lead to changes in the aquatic ecosystems, which may also be at serious risk. Among the aquatic ecosystems of the Atlantic Forest, there is an complex of ca. 250 lakes located

\footnotetext{
${ }^{1}$ Laboratório de Ficologia, Departamento de Botânica, Universidade Federal de Minas Gerais, 31270-901, Belo Horizonte, MG, Brazil

${ }^{2}$ Laboratório de Pesquisa Ambiental, Curso de Engenharia Ambiental e Sanitária, Centro Universitário do Leste de Minas Gerais, 35170-056, Coronel Fabriciano, MG, Brazil

* Corresponding author: cleberfigueredo@ufmg.br
} 
The necessity of management in a lake of the Atlantic Forest biodiversity hotspot: nitrogen levels connected to a persistent bloom of Cylindrospermopsis raciborskii

in the middle Rio Doce basin (Barros et al. 2013), which is the third largest system of lakes in Brazil. Only about 50 lakes are located in an environmental reserve, the "Rio Doce State Park", an important conservation area that was included in the Ramsar list for conservation and sustainable utilization of wetlands, based on its ecological, economic, scientific, cultural and recreational value (Ramsar 2010). Lakes within the park have been studied since the 1970s, mostly focusing on two lakes, Dom Helvécio and Carioca (Henry \& Barbosa 1989; Bezerra-Neto \& Pinto-Coelho 2008; Barros et al. 2013). Several other lakes are also found in private areas outside the park, where the natural forest was cleared to make way to Eucalyptus plantations and pastures (Barros et al. 2013). These systems are poorly studied, although their preservation is as important as the preservation of the lakes inside the Park, since they are strongly connected, increasing the local impact to a regional dimension (Latini \& Petrere 2004). Because they are often used as recreational areas, the maintenance of their ecological integrity would provide an environment with suitable water quality.

Considering the threats to biological diversity in aquatic ecosystems, phytoplankton responses are useful to evaluate some aspects of the environmental degradation (Cairns et al. 1993). Phytoplankton is very sensitive to the impacts on aquatic ecosystems (Huertas et al. 2011) and nutrient (mainly $\mathrm{N}$ and $\mathrm{P}$ ) enrichment generally results in its massive growth (Elser et al. 1990; Yang et al. 2008). Other common response to eutrophication is the change in the community structure by the selection of certain morphological or physiological types (Vinebrooke et al. 2004). The result is often the dominance of species or groups favored by these modified environmental conditions, such as mixotrophic flagellates and cyanobacteria (Watson et al. 1997; Giani et al. 2005; Soares et al. 2013). Cyanobacteria, or blue-green algae, can be especially dangerous due to their potential toxicity to humans and animals (Carmichael et al. 2001). Although it is not a common feature in microrganisms, some phytoplankton species are considered invaders, such as the potentially toxic cyanobacteria Cylindrospermopsis raciborskii (Padisák 1997). This species occurs in lakes of the Rio Doce region, with moderate densities in Dom Helvécio Lake (Souza et al. 2008), but producing blooms in some waterbodies outside the protected area of the park. In the Pedalinhos lake, for example, C. raciborskii appears to bloom according to the availability of nutrients, especially nitrogen (Figueredo et al. 2014).

Although the relationship between phytoplankton and nutrients is relatively well known (Smith 2003), it is not completely understood the exact role of $\mathrm{P}$ and $\mathrm{N}$ in the changes observed during the eutrophication process (Elser et al. 1990), particularly in the tropics and subtropics (Yang et al. 2008; Xu et al. 2010). The statement that phytoplankton responses would be more previsible in consequence of changes in P levels was the basis for the idea that controlling
P concentrations should be the best strategy to restore water quality, what was named by Sterner (2008) as the "phosphorus limitation paradigma". However, even if $\mathrm{P}$ is often considered more limitant in freshwater, there are studies showing that both nutrients are important for the environment functioning (Elser et al. 1990; Dzialowski et al. 2005).

Here, we examined the Marola Lake, a natural lentic water body that belongs to the Rio Doce lake system, but it is located outside the preserved area of the State Park. This lake presented high cyanobacteria densities in the last years (Veloso et al. 2011), but the major causes of these events are not yet well known. Furthermore, there is still limited knowledge about the phytoplankton community of this lake and many other lakes situated outside the Park. Our hypothesis was that the climatic oscillation in the region may be controlling the seasonality of the water quality, with changes in $\mathrm{N}$ and $\mathrm{P}$ levels and consequent modification in the phytoplankton total biomass and structure. We were also expecting that nitrogen would play an important role as a limitant nutrient in the water, since it is commonly scarce in the soil of this biome (Groppo et al. 2015) and no waste is released into this lake.

\section{Materials and Methods}

Our study was performed in Marola Lake (19 $18^{\prime} 52^{\prime \prime} .15$ S and $42^{\circ} 24^{\prime} 20^{\prime \prime} .86 \mathrm{~W}$ ), a natural water body situated in the middle Rio Doce basin, in Southeastern Brazil, belonging to a system of around 150 lakes located just a few kilometers apart from each other (Fig. 1). It has a surface area of 36.9 ha and $4.2 \mathrm{~m}$ of maximum depth. In the watershed area around Marola Lake (302.3 ha), the original Atlantic Forest was replaced by secondary forest (83.73 ha) and Eucalyptus L'Heritier plantations (153.38 ha). Currently, only $60 \%$ of the Eucalyptus cover is being used for cellulose production, and the rest is left untouched. The altitude is of about $230 \mathrm{~m}$ and the climate is tropical wet and dry or Aw, according to the Köppen climate classification. The average temperature is $22^{\circ} \mathrm{C}$ and average annual rainfall is 1778 $\mathrm{mm}$ (Tavares et al. 2007). There is a striking seasonality with a dry season lasting from May to September and a rainy season from October to April. The climate affects the water column stability and the lakes of the region are characterized by mixing during the dry/colder months and stratification during warm/rainy season (Tundisi 1997). Marola Lake is located in a private area and has been used for recreational purposes, but the increasing eutrophication worsened the water conditions that show now high concentration of nutrients and chlorophyll $a$ and high densities of cyanobacteria (Veloso et al. 2011).

In this study, water samples were taken monthly from June 2011 to April 2013. Considering the small dimension of Marola Lake, only one sampling point was chosen (Fig. 1 ) as representative of the lake. The local depth was about 


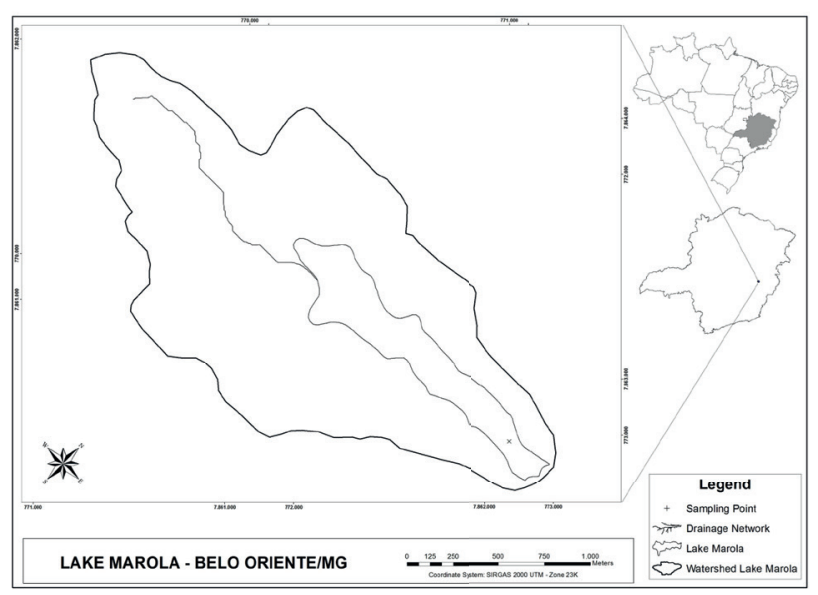

Figure 1. Sampling point and geographic location of Marola Lake.

$3 \mathrm{~m}$, and sampling consisted of an integration of samples taken at the surface and Secchi depth, both obtained with a Van Dorn bottle. The samples were processed in the laboratory, as explained hereafter. An aliquote of the water sample was preserved with Lugol's iodine solution for posterior phytoplankton quantification using an inverted microscope, according to the Utermöhl technique (1958). For phytoplankton, sampling was performed bimonthly up to the end of 2011, becoming monthly after February 2012. Species biovolumes were estimated from cell numbers and mean cell volumes, calculated according to Sun \& Liu (2003).

In situ values of conductivity, dissolved oxygen (DO), $\mathrm{pH}$, temperature, and total dissolved solids were measured with a Hanna ${ }^{\circledR} 9828$ multiparameter probe. Samples were immediately brought to the laboratory, where aliquots of raw water were frozen for total phosphorus (total-P) and nitrogen (total-N) analyses. A sub-sample was filtered through GF-5 glass fiber filters (Macherey-Nalgen ${ }^{\circledR}$ ) for chlorophyll $a$ analysis, done by acetone extraction according to APHA (2005). The filtered water was used for the determination of soluble reactive phosphorus (SRP), ammonium $\left(\mathrm{NH}_{4}{ }^{+}\right)$, nitrite $\left(\mathrm{NO}_{2}^{-}\right)$, and nitrate $\left(\mathrm{NO}_{3}^{-}\right)$concentrations. Total suspended solids (TSS) were measured on the particulate material retained in a GF-3 glass fiber filters (MachereyNalgen), using gravimetric method. Determinations of volatile and fixed fractions were performed by igniting the sample at $550^{\circ} \mathrm{C}$ (APHA 2005). The filtrates and filters were kept frozen until analysis. SRP and turbidity were evaluated in the sampling day, using filtrate and raw water samples, respectively. These analyses were performed spectrophotometrically using the Spectroquant Merck ${ }^{\circledR}$ method. Colorimetric methods were employed for nutrients after some preparation using the Spectroquant Merck ${ }^{\circledR}$ or according to standardized methods by APHA (2005). In synthesis, concentrations of $\mathrm{NH}_{4}{ }^{+}$were measured by the phenate method, while total- $\mathrm{N}$ was oxidized to $\mathrm{NO}_{3}^{-}$that was converted to $\mathrm{NO}_{2}{ }^{-}$by cadmium reduction method or directly measured after a reaction with benzoic acid or
2,6 dimethylphenol. Total-N digestion was performed by persulfate, and total-P digestion by sulfuric acid/nitric acid. After the analyses, molar total-N:total-P and DIN:total-P ratios were calculated to evaluate nutrients availability. Rainfall data were provided as monthly means by CENIBRA S.A. meteorological station (Belo Oriente City), located at ca. $1.5 \mathrm{~km}$ from Marola Lake.

Before performing the statistical analyses, the data pool was tested for normality using Shapiro-Wilk test and for homoscedasticity using Brown-Forsythe test. Since data did not show normality nor homoscedasticity, they were log10transformed before running the parametric analyses under a similar scale. To extract the main tendencies between environmental variables and phytoplankton, and also in order to verify the existence of seasonal differences in the dataset, a principal component analysis (PCA) was performed using the PAST Software (Hammer et al. 2001). The major variables describing the variability of data pool were identified and selected for further statistical analyses. Hence, the connections among biological, physical, and chemical variables were evaluated by Pearson correlation analysis, generating a correlation matrix calculated for 10 variables ( $n=19$ observations for each variable). For the correlation analyses involving phytoplankton biomass, we selected biovolume over chlorophyll, since the two variables were highly correlated, but the biovolume allowed the description of trends for the major taxonomic groups.

\section{Results}

Table 1 synthesizes the water condition during the study period. The data showed that Marola Lake is currently eutrophic, with high mean concentrations of N, P and chlorophyll a. Water temperature was always high. Water transparency was generally low and dissolved oxygen was generally abundant, but concentrations as low as $4.4 \mathrm{mg}$. $\mathrm{L}^{-1}$ were sometimes observed. Phosphorus availability was mainly estimated by total phosphorus concentrations, since SRP was not detected in the majority of samples, except in two cases, when concentrations of 13 and $23 \mu \mathrm{g} . \mathrm{L}^{-1}$ were respectively recorded in May and November 2012. Dissolved nitrogen forms showed very large variation range, with no detectable levels being frequently registered.

Rainfall and water temperature exhibited the typical pattern for the region, with rains concentrated in the warm period of spring and summer and the dry period occurring during autumn and winter, characterized by lower temperatures (Fig. 2). Although water temperature showed oscillations, it was always high, with values between $22{ }^{\circ} \mathrm{C}$ and $30^{\circ} \mathrm{C}$. The rainfall covered a very wide range, varying from $0 \mathrm{~mm}$ in June/July to more than $300 \mathrm{~mm}$ in December 2011. Due to this marked variation, the rainfall data were not included in PCA as a numeric variable, but they were used to separate samples in two groups, one containing samples from rainy and other from dry months. 
The necessity of management in a lake of the Atlantic Forest biodiversity hotspot: nitrogen levels connected to a persistent bloom of Cylindrospermopsis raciborskii

Table 1. Physical, chemical and biological (chlorophyll a) variables in Marola Lake. The variation range shows minimum and maximum values. Mean values and standard deviation are also presented. $\left(\mathrm{DO}=\right.$ dissolved oxygen, $\mathrm{SRP}=$ soluble reactive phosphorus, $\mathrm{NH}_{4}{ }^{+}=$ ammonium concentration, $\mathrm{NO}_{2}{ }^{-}+\mathrm{NO}_{3}{ }^{-}=$sum of the concentrations of nitrite and nitrate).

\begin{tabular}{|c|c|c|}
\hline & Variation range & Mean [ \pm Standard Deviation] \\
\hline Temperature $\left({ }^{\circ} \mathrm{C}\right)$ & $22.0-30.7$ & $26.7(2.7)$ \\
\hline Secchi depth (m) & $0.25-0.80$ & $0.43(0.17)$ \\
\hline $\mathrm{DO}\left(\mathrm{mg} \cdot \mathrm{L}^{-1}\right)$ & $4.4-11.9$ & $7.2(2.3)$ \\
\hline Alkalinity $\left(\mathrm{mEq} \cdot \mathrm{L}^{-1}\right)$ & $14.6-22.8$ & $18.4(1.9)$ \\
\hline $\mathrm{pH}$ & $6.3-8.8$ & $7.3(0.6)$ \\
\hline Total suspended solids $\left(\mathrm{mg} \cdot \mathrm{L}^{-1}\right)$ & $3.0-37.8$ & $20.0(9.7)$ \\
\hline $\operatorname{SRP}\left(\mu \mathrm{g} \cdot \mathrm{L}^{-1}\right)$ & $0-23$ & $1.8(5.9)$ \\
\hline Total-P $\left(\mu g \cdot \mathrm{L}^{-1}\right)$ & $12-150$ & $55.6(54.4)$ \\
\hline $\mathrm{NH}_{4}^{+}\left(\mu \mathrm{g} \cdot \mathrm{L}^{-1}\right)$ & $0-720$ & $237.4(216.1)$ \\
\hline $\mathrm{NO}_{2}^{-}+\mathrm{NO}_{3}^{-}\left(\mu \mathrm{g} \cdot \mathrm{L}^{-1}\right)$ & $0-410$ & 75.9 (109) \\
\hline Total-N $\left(\mu \mathrm{g} \cdot \mathrm{L}^{-1}\right)$ & $742-2478$ & $1533.1(414.5)$ \\
\hline Chlorophyll $a\left(\mu \mathrm{g} \cdot \mathrm{L}^{-1}\right)$ & $2-57.4$ & 21.7 (18.2) \\
\hline
\end{tabular}

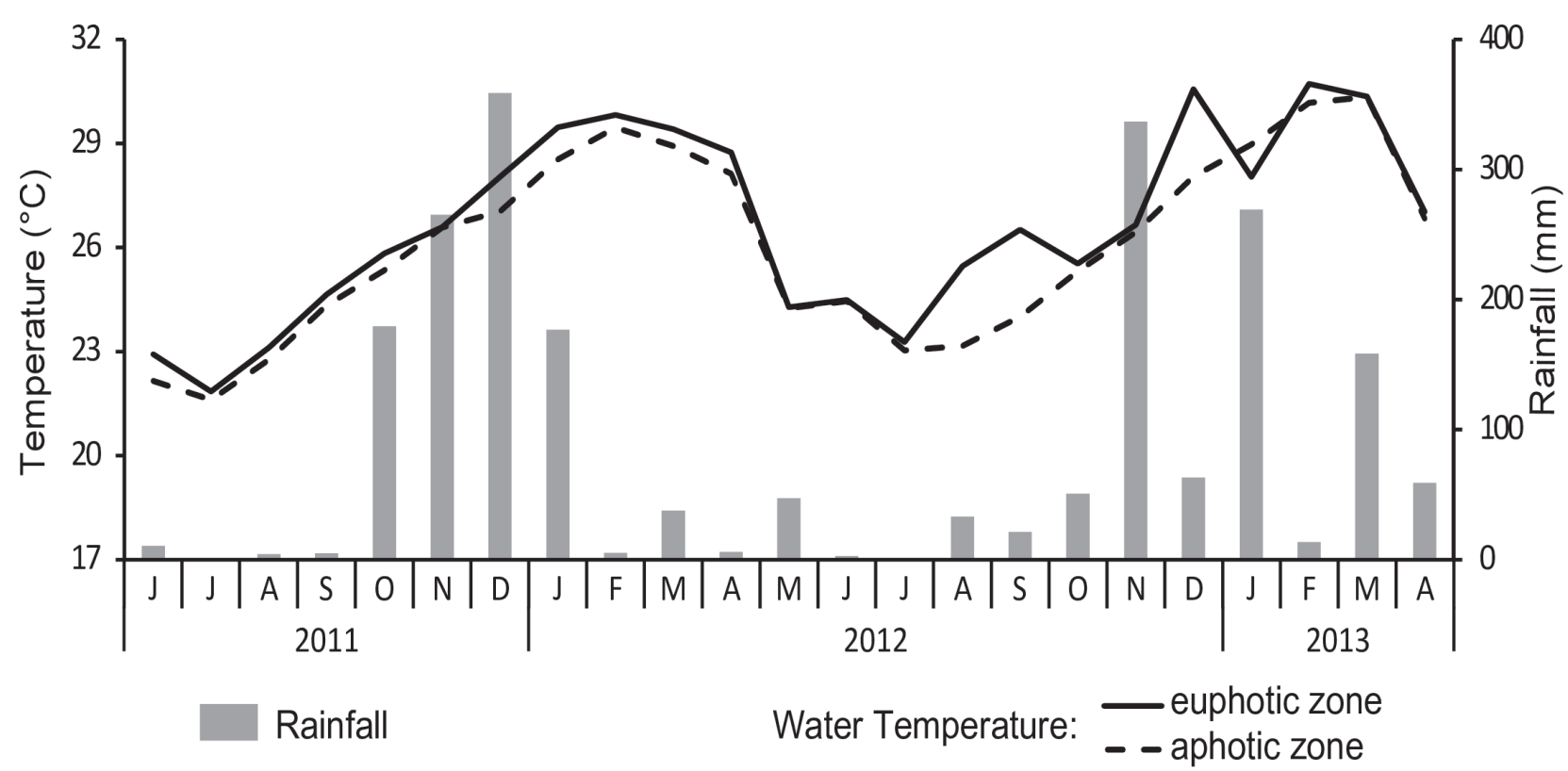

Figure 2. Temporal variation of rainfall and water temperature in the Marola Lake along the studied period.

This strategy allowed identifying particularities related to seasonality of physical, chemical and biological variables. The seasonality of water conditions was evident since the principal component analysis resulted in two groups of points, in which samples obtained during the dry season separated from those of the rainy season (Fig. 3) mainly in relation to the factor 2 . The PCA also showed that chlorophyll $a$ (representing the phytoplankton biomass), water transparency and nutrient concentrations, mainly dissolved $\mathrm{N}$ and total-P, were the 'master variables' driving the changes in water characteristics and they represented about $85 \%$ of the total variability in Marola Lake. The first axis explained $56.6 \%$ of the total variability and it was strongly correlated with $\mathrm{NH}_{4}^{+}$and, to a lesser extent, with chlorophyll- $a$ and Secchi depth. The second axis accounted for $28.0 \%$ of the total variability and it was correlated to the other inorganic $\mathrm{N}$ sources $\left(\mathrm{NO}_{2}^{-}+\mathrm{NO}_{3}^{-}\right)$and total-P (Fig. 3). Since transparency, nutrients and phytoplankton (all connected with water trophy) were the major variables describing Marola Lake we have focused on the relations between them to identify the conditions promoting the massive phytoplankton growth observed along the last years. Thus, further analyses were performed considering temporal aspects to allow the evaluation of seasonality. SRP measurements were not considered for statistical analyses, because the concentrations were frequently below the detection limit of the method $\left(<10 \mu \mathrm{g} . \mathrm{L}^{-1}\right)$.

Chlorophyll- $a$ and phytoplankton biovolume were highly correlated $(r=0.78, \mathrm{P}<0.01)$ (Fig. 4$)$, and the variation of phytoplankton biomass during the study period was characterized by no clear seasonal trend. Very high biovolume values (reaching $100 \mathrm{~mm}^{3}$. $\mathrm{L}^{-1}$ ) were recorded during the warmer and rainy season at the end of 2012. The temporal changes of the phytoplankton biovolume were almost totally shaped by the cyanobacteria. This fact was especially related to Cylindrospermopsis raciborskii, the dominant species in 


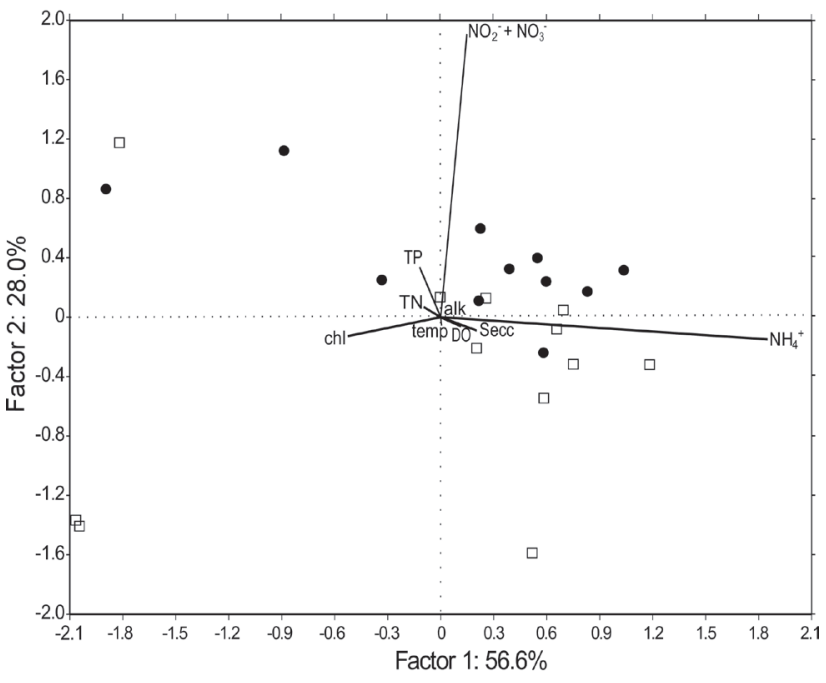

Figure 3. PCA ordination for the environmental variables on the main factor-plane for Marola Lake. Filled circles represent months of the dry season, while open squares represent months of the rainy season. ( $\mathrm{DO}=$ dissolved oxygen, $\mathrm{Secc}=$ Secchi transparency, temp = water temperature, $\mathrm{TP}=$ total $-\mathrm{P}, \mathrm{TN}=$ total $-\mathrm{N}$, alk = alkalinity, $\mathrm{chl}$ = chlorophyll a concentration, $\mathrm{NH}_{4}{ }^{+}=$ammonium concentration, $\mathrm{NO}_{2}{ }^{-}+\mathrm{NO}_{3}{ }^{-}=$sum of the concentrations of nitrite and nitrate).

the majority of the samples (Fig. 4). Pearson correlation analysis showed a very high coefficient $(r=0.97, \mathrm{P}<0.001)$ between this species and total phytoplankton biovolume. Heterocysts were recorded just once (August 2012) and at very low frequency (in $2.2 \%$ of the trichomes).

The evaluation of correlations between phytoplankton biovolume and the major physico-chemical variables (according to the PCA) was an attempt to identify factors governing phytoplankton growth in Marola Lake. Total-P exhibited clear seasonality, with higher concentrations in the dry season and it was not clearly related to phytoplankton
(Fig. 5A), since Pearson correlation was not significant $(\mathrm{r}=$ $0.194, P=0.43)$. The sum of nitrite and nitrate had a less clear seasonal pattern, but higher values were also generally observed in dry season (Fig. 5B). These nitrogen sources were also not correlated with phytoplankton biovolume ( $\mathrm{r}$ $=0.09, \mathrm{P}=0.72$ ), since the highest biovolume values were observed for both high and low $\mathrm{NO}_{2}{ }^{-}+\mathrm{NO}_{3}{ }^{-}$concentrations (Fig. 5B). Ammonium had no seasonal tendency, but it was highly correlated to phytoplankton biovolume, showing a significant inverse correlation $(r=-0.83, P<0.001)$ (Fig. 5C). A significant inverse correlation was also observed between phytoplankton and Secchi depth $(r=-0.82, \mathrm{P}<$ 0.001) (Fig. 5D). Even with some temporal variation in nutrients availability, with higher $\mathrm{N}: \mathrm{P}$ ratios at the end of rainy season and beginning of dry season, TN:TP and DIN:TP ratios (often lowest than 30 and 3, respectively) were always lower than the levels established by Ferber et al. (2004, see discussion for details) (Fig. 6). Phytoplankton biovolume and the most abundant species, C. raciborskii, showed significant $(\mathrm{P}<0.01)$ correlations with DIN:TP, but not significant $(\mathrm{P}>0.19)$ with TN:TP ratios (Tab. 2$)$, or with absolute concentrations of Total-P $(\mathrm{P}>0.3$ for both correlations).

\section{Discussion}

Marola Lake proved to be a very dynamic system, with intense temporal changes highlighted by high standard deviation, low minimum and very high maximum values often recorded for TSS, SRP, total-P, dissolved nitrogen sources and chlorophyll $a$. Such wide variations in water quality are common in small water bodies, due to their little volumetric buffer capacity and proportionally high perimeter (Read \& Rose 2013), making these environments more sensitive to disturbances that may be occurring in the

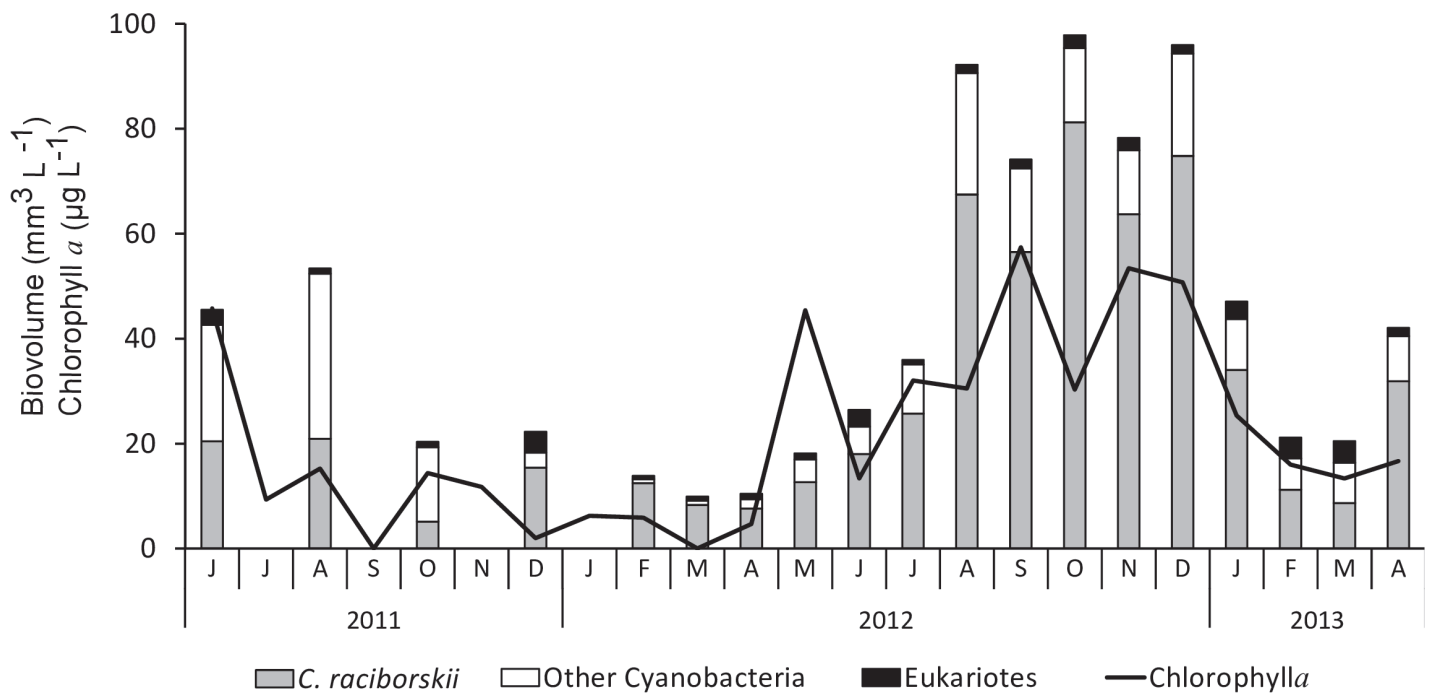

Figure 4. Temporal variation of phytoplankton biovolume and chlorophyll a concentrations along the studied period. 
The necessity of management in a lake of the Atlantic Forest biodiversity hotspot: nitrogen levels connected to a persistent bloom of Cylindrospermopsis raciborskii

Table 2. Pearson correlation matrix for data of phytoplankton and N:P ratios. (DIN = dissolved inorganic nitrogen).

$\begin{array}{lcc} & \text { r coefficient } & \text { P-value } \\ \text { DIN:total-P x total biovolume } & -0.61^{*} & 0.006 \\ \text { DIN:total-P x C. raciborskii } & -0.60^{*} & 0.007 \\ \text { Total-N:total-P x total biovolume } & -0.30 & 0.198 \\ \text { Total N:total-P x C. raciborskii } & -0.24 & 0.326\end{array}$

$\left.{ }^{*}\right)$ significant correlation $(\mathrm{P}<0.05)$
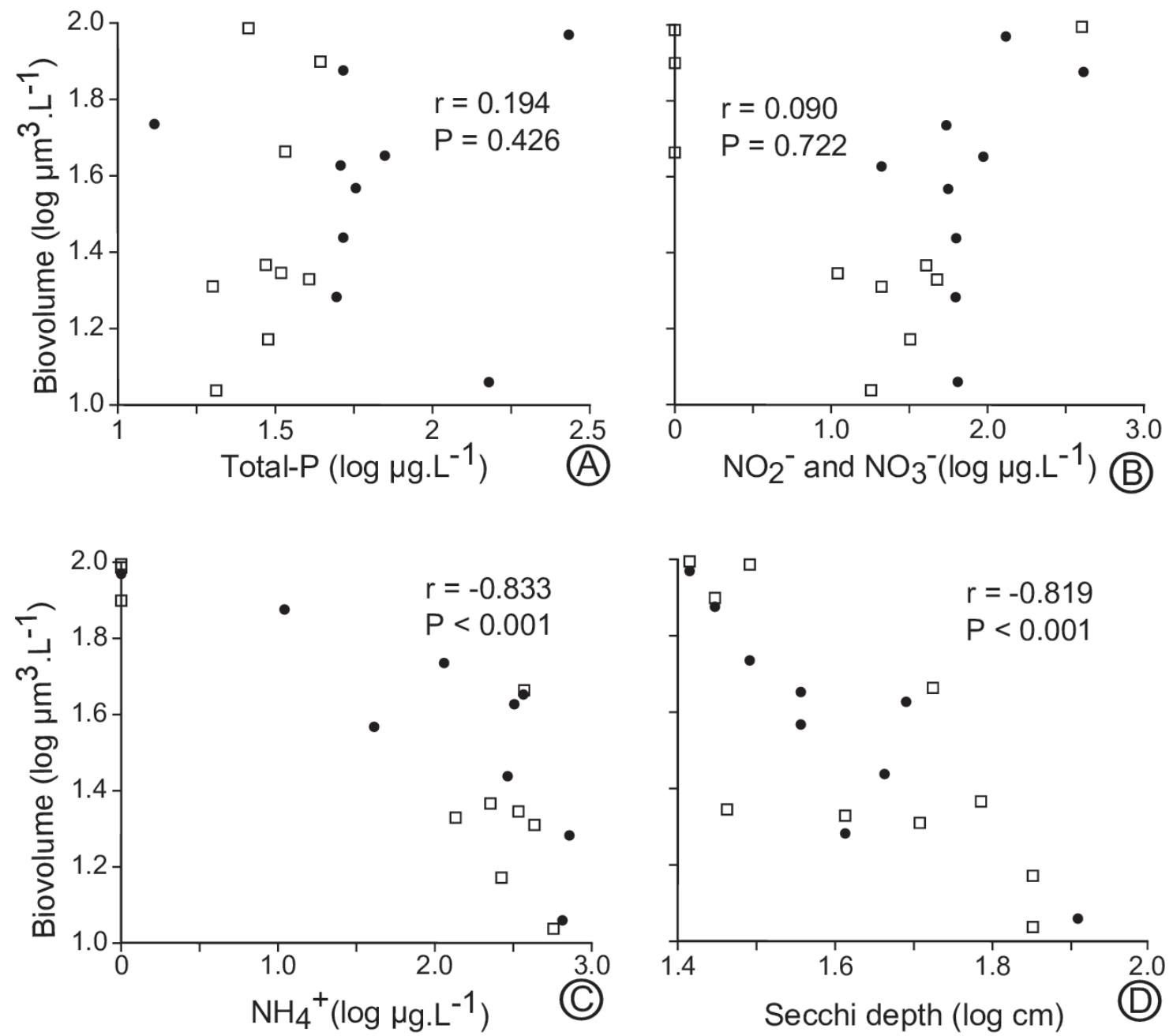

Figure 5. Correlations between phytoplankton biovolume and the major physico-chemical variables $\left(\mathrm{A}=\mathrm{Total}-\mathrm{P}, \mathrm{B}=\mathrm{NO}_{3}^{-}+\mathrm{NO}_{2}^{-}\right.$, $\mathrm{C}=\mathrm{NH}_{4}^{+}$and $\mathrm{D}=$ Secchi depth) pointed by the PCA analysis. Filled circles represent months of the dry season, while open squares represent months of the rainy season.

surroundings (Anderson 2014). The prompt responses allow the rapid detection of changes or impacts happening in the watersheds and could be helpful to understand the effects of land use, providing supporting data for the conservation of endangered environments, such as biodiversity hotspots (Boëchat et al. 2011). The water quality in Marola Lake was connected to climate events, which was observed in the PCA ordination that clearly separated dry and rainy seasons. Other lentic water bodies in the same region showed similar tendencies and pointed to rain as the major climatic force driving changes in their water quality (e.g. Barros et al. 2006; Figueredo et al. 2014), since rains may be sufficiently intense in the tropics to cause dilution of many ions and nutrients in the water (Figueredo \& Giani 2001). For Marola Lake, climate clearly affected total-P and $\mathrm{NO}_{2}^{-}+\mathrm{NO}_{3}^{-}$concentration, which lower values were recorded in the rainy season. However, the other variables did not exhibit cyclic seasonality.

A more interesting result of the PCA was the identification of variables that summarize the water 


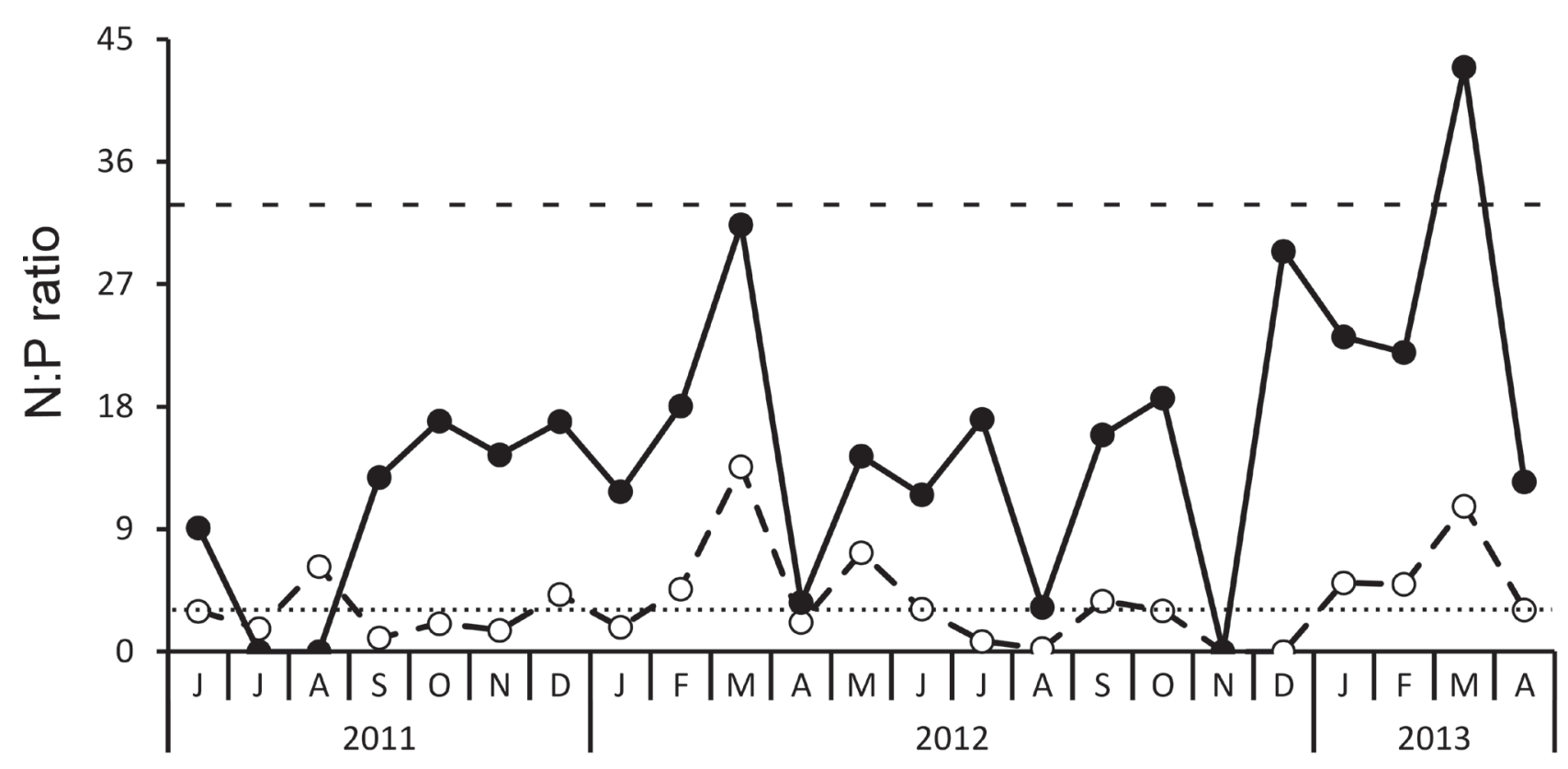

Figure 6. Temporal variation of DIN:TP (open circles) and TN:TP (closed circles) ratios along the studied period. The limitant levels of DIN:TP (3) and TN:TP (33) ratios suggested by Ferber et al. (2004) are also represented by the horizontal lines.

condition. Since nutrients, phytoplankton (measured as chlorophyll concentration) and transparency were in evidence, trophy was the major factor describing variability. Even presenting wide oscillations, the high maximum and mean concentrations of total-P and chlorophyll $a$, and the low values of Secchi depth proved that this lake is eutrophic (see classification systems established by OECD 1982; Lamparelli 2004; Huszar et al. 2006). Regarding temporal variations, some of the major variables pointed by the PCA were significantly correlated to phytoplankton, and helped explaining the observed trends. The strong negative correlation between phytoplankton and water transparency is more obvious and generally explained by the high phytoplankton biomass causing an increase in turbidity (Branco \& Senna 1996; Figueredo et al. 2014). Independent of the causes of a low turbidity, its consequence is a favorable condition for the dominant Cylindrospermopsis raciborskii, which has a competitive advantage by growing efficiently under shadow conditions (Bouvy et al. 1999; Kokocinski \& Soininen 2012). This dominance is a problem since this species is considered invasive in many ecosystems (Padisák 1997) and the South-American strains can produce potent neurotoxins (Lagos et al. 1999; Neilan et al. 2003; Piccini et al. 2011). Cylindrospermopsis raciborskii blooms reported in Marola Lake are another evidence of its eutrophic condition, once cyanobacteria blooms generally occur parallel to nutrient enrichment (Watson et al. 1997). Due to the water quality deterioration resulting from cyanobacteria growth, freshwater researchers and managers are trying to identify their major causes (Giani et al. 2005; Wagner \& Adrian 2009) and this became part of our goal in this study.

Several authors have pointed to the limitation of certain resources ( $\mathrm{N}, \mathrm{P}, \mathrm{CO}_{2}$ and light) as the major factors related to cyanobacterial blooms due to their competitive superiority (Scheffer et al. 1997; Mischke 2003). Blomqvist et al. (1994) suggested that interactions could be more specific and hypothesized that not only the total-N availability, but its different forms would define the dominant group in the phytoplankton community, which was reinforced by Ferber et al. (2004). These authors predicted dominance by eukaryotes when $\mathrm{NO}_{3}{ }^{-}$is the major $\mathrm{N}$ source, and cyanobacteria dominance would be strongly connected to $\mathrm{NH}_{4}{ }^{+}$availability, since this phylum seems to be able to grow faster in this nitrogen source (e.g. Herrero et al. 2001; Rückert \& Giani 2004). As observed in Marola Lake, other studies have demonstrated that $\mathrm{NH}_{4}{ }^{+}$may be the major DIN source in some eutrophic ecosystems (e.g. Axler et al. 1981; Fisher et al. 1988; Ferber et al. 2004), and increasing $\mathrm{NH}_{4}^{+}$ concentrations could favor some cyanobacteria species in deteriorated systems. However, not all cyanobacteria show the same response to $\mathrm{N}$ availability. Cylindrospermopsis raciborskii, for example, is a species that seems to show a competitive advantage under lack of nitrogen sources, mainly $\mathrm{NH}_{4}^{+}$(Padisák 1997; Figueredo et al. 2014). It can fix atmospheric nitrogen and can even be a superior competitor for ammonium and this could be the causes of the negative connection between this species and ammonium availability (Padisák 1997), as observed in Marola Lake.

Trying to understand the conditions favoring massive development of $C$. raciborskii is fundamental for the management and conservation of water bodies apparently invaded by this species. Cyanobacteria are often controlled by temperature, producing blooms in the warmest seasons (Bouvy et al. 1999; McGregor \& Fabbro 2000; Figueredo 
\& Giani 2001; Gomes et al. 2012). The relatively stable temperature in the optimum range (above $22^{\circ} \mathrm{C}$ ) for cyanobacteria (Soares et al. 2013; Chen 2015) must have contributed to the constant $C$. raciborskii dominance, as noted by Figueredo \& Giani (2009) in Lagoa Santa, Brazil. Hence, it is possible that additional environmental factors could better explain the fluctuations observed in its biomass.

Nutrients (mainly $\mathrm{N}$ and $\mathrm{P}$ ) are generally very important to determine phytoplankton dynamics and tendencies. The constantly undetectable $\left(<10 \mu \mathrm{g} . \mathrm{L}^{-1}\right)$ SRP levels, even during periods of high TP concentrations, is probably a consequence of the fast SRP assimilation by the biological community (Dodds 2003). Thus, TP was the unique variable used to describe P availability in Marola Lake. However, the absolute concentration of nutrients, discussed in the text above, are not always sufficient to explain the structure and dynamics of the phytoplankton community. Therefore, the Nitrogen:Phosphorus ratio is often used for this purpose, even though units (p. ex. TN:TP, DIN:TP) are frequently different, depending on authors and studies.

When considering the TN:TP ratios, Marola Lake appears to be almost constantly limited by $\mathrm{N}$ since values were lower than 29 (Smith 1983) or 33 (see the study of Ferber et al. 2004, based on Morris \& Lewis 1988), which are considered important limits determining changes in phytoplankton structure. The relative lack of nitrogen could be favoring the stable dominance of $C$. raciborskii, considered a superior competitor for N (Padisák 1997; Kokocinski \& Soininen 2012; Figueredo et al. 2014). The influence of nutrients in $C$. raciborskii dynamics was even more evident when considering the oscillations of DIN:TP, which showed alternated periods of $\mathrm{N}$ limitation with others with $\mathrm{N}$ sufficient conditions. This temporal variation allowed the identification of significant correlations between cyanobacteria and nutrient availability. Although there was no significant correlation between absolute TP values and $C$. raciborskii biovolume, the temporal variation of this species was connected with nutrients ratios. DIN:TP ratios showed a significant negative correlation with C. raciborskii biovolume, which became more abundant when DIN:TP ratios were under the limiting level (ratio = 3), established by Ferber et al. (2004). The lack of DIN can limit the development of eukaryotic phytoplankton and cyanobacteria gain dominance by presenting superior competitiveness for $\mathrm{N}$, even beyond $\mathrm{N}_{2}$ fixation (Ferber et al. 2004). These authors observed dominance of $\mathrm{N}$-fixers even during periods of low $\mathrm{N}_{2}$ fixation and concluded that fixation is a mechanism allowing them to outcompete other phytoplankton species, but it is probably not the only one.

According to Marotta et al. (2012), the natural lakes in the Atlantic Forest are especially sensitive to degradation. In Marola Lake, we detected important changes in physical, chemical and phytoplankton data. Since lakes are located in the lower lands of the watersheds, they are very sensitive to human impacts occurring in the upper regions. Consequently, they also must be taken into account, when planning for biodiversity conservation in the Atlantic
Forest remnants. Considering the intense degradation of the tropical Atlantic Forest and the lack of knowledge about the natural water bodies of this biome, this study can contribute to the identification and understanding of the vulnerability of these ecosystems to anthropic influences. The Marola Lake was characterized by eutrophic conditions, and phytoplankton is growing here under a low N:P ratio, which is one potential cause of the persistent bloom of an invasive cyanobacteria (C. raciborskii), in general considered a superior $\mathrm{N}$ competitor (Padisák 1997). Since this species can be toxic, Marola Lake is not adequate for many uses nowadays. It is probable that the P input into Marola Lake could result from several human activities in watershed, including fertilization. In addition, it is also possible that the low N:P ratio in the water is a consequence of the low $\mathrm{N}$ availability in the Atlantic Forest soil, a condition that is even more evident in the areas submitted to human impacts (Groppo et al. 2015). This fact could highlight that degradation could drive other lentic systems in the Atlantic Forest to these blooms occurrence, which could be very deleterious for the water quality. Besides the fact that these blooms are a risk for many species, they could be even more critical when affecting water bodies used for recreational purposes, such as Marola Lake. Along with the more common attention paid to the $\mathrm{P}$ dynamics, $\mathrm{N}$ availability should be considered for the management of this lake and possibly for other lakes in the same region.

\section{Acknowledgements}

We acknowledge the Celulose Nipo-Brasileira S.A. (CENIBRA) for providing the permission and support during the study in Marola Lake. We also thank Dimitri von Rückert for linguistic corrections. We are grateful to the logistical and financial support granted by Centro Universitário do Leste de Minas Gerais (UNILESTE), CENIBRA and Fundação Geraldo Pelingeiro Abreu (FPGA).

\section{References}

Anderson J. 2014. Landscape disturbance and lake response: temporal and spatial perspectives. Freshwater Reviews 7:77-120.

APHA - American Public Health Association. 2005. Standard Methods for the Examination of Water and Wastewater. 21 edn. Washington , APHA.

Axler RP, Redfield GW, Goldman CR. 1981. The importance of regenerated nitrogen to phytoplankton productivity in a subalpine lake. Ecology 62: 345-354.

Barros CFA, Souza MBG, Barbosa FAR. 2006. Seasonal forces driving phytoplankton size structure dynamics in a tropical deep lake (Dom Helvécio Lake, South-East Brazil). Acta Limnologica Brasiliensia 18: 55-66

Barros CFA, Santos AMM, Barbosa FAR. 2013. Phytoplankton diversity in the middle Rio Doce lake system of southeastern Brazil. Acta Botanica Brasilica 27: 327-346

Bezerra-Neto JF, Pinto-Coelho RM. 2008. Morphometric study of Lake Dom Helvécio, Parque Estadual do Rio Doce (PERD), Minas Gerais, Brazil: a re-evaluation. Acta Limnologica Brasiliensia 20: 161-167. 


\section{Cleber Cunha Figueredo, Gabriela von Rückert \\ and Alessandra Giani}

Blomqvist P, Pettersson A, Hyenstrand P. 1994. Ammonium - nitrogen: A key of non-nitrogen fixing cyanobacteria in aquatic systems. Archive für Hydrobiologie 132: 141-164

Boëchat IG, Angela K, Giani A, Figueredo CC, Gücker B. 2011. Agricultural land-use affects the nutritional quality of stream microbial communities. FEMS Microbiology Ecology 77: 568-576.

Bouvy M, Molica R, Oliveira S, Marinho M, Beker B. 1999. Dynamics of a toxic cyanobacterial bloom (Cylindrospermopsis raciborskii) in a shallow reservoir in the semi-arid region of northeast Brazil. Aquatic Microbial Ecology 20: 285-297.

Branco CWC, Senna PAC. 1996. Relations among heterotrophic bacteria, chlorophyll a, total phytoplankton, total zooplankton and physical and chemical features in the Paranoá reservoir, Brasília, Brazil. Hydrobiologia 337: 171-181.

Cairns J, McCormick PV, Niederlehner BR. 1993. A proposed framework for developing indicators of ecosystem health. Hydrobiologia 263: 1-44.

Carmichael WW, Azevedo SMFO, An JS, et al. 2001. Human fatalities from cyanobacteria: chemical and biological evidence for cyanotoxins. Environmental Health Perspectives 109: 663-668.

Chen B. 2015. Patterns of thermal limits of phytoplankton. Journal of Plankton Research 37: 285-292.

Dodds WK. 2003. Misuse of inorganic N and soluble reactive P concentrations to indicate nutrient status of surface waters. Journal of the North American Benthological Society 22: 171-181.

Dzialowski AR, Wang SH, Lim NC, Spotts WW, Huggins DG. 2005. Nutrient limitation of phytoplankton growth in central plains reservoirs, USA. Journal of Plankton Research 27: 587-595.

Elser JJ, Marzolf ER, Goldman CR. 1990. Phosphorus and Nitrogen Limitation of Phytoplankton Growth in the Freshwaters of North America: A Review and Critique of Experimental Enrichments. Canadian Journal of Fisheries and Aquatic Sciences 47: 1468-1477.

Ferber LR, Levine SN, Lini A, Livingston GP. 2004. Do cyanobacteria dominate in eutrophic lakes because they fix atmospheric nitrogen? Freshwater Biology 49: 690-708.

Figueredo CC, Giani A. 2001. Seasonal variation in the diversity and species richness of phytoplankton in a tropical eutrophic reservoir. Hydrobiologia 445: 165-174.

Figueredo CC, Giani A. 2009. Phytoplankton community in the tropical lake of Lagoa Santa (Brazil): conditions favoring a persistent bloom of Cylindrospermopsis raciborskii. Limnologica 39: 264-272.

Figueredo CC, Rückert G, Cupertino A, et al. 2014. Lack of nitrogen as a causing agent of Cylindrospermopsis raciborskii intermittent blooms in a small tropical reservoir. FEMS Microbiology Ecology 87: 557-567.

Fisher TR, Morrissey KM, Carlson PR, Alves LF, Melack JM. 1988. Nitrate and ammonium uptake by plankton in an Amazon River floodplain lake. Journal of Plankton Research 10: 7-29.

Giani A, Bird DF, Praire YT, Lawrence JF. 2005. Empirical study of cyanobacterial toxicity along a trophic gradient of lakes. Canadian Journal of Fisheries and Aquatic Sciences 62: 2100-2109.

Gomes LNL, Oliveira SMAC, Giani A, Sperling EV. 2012. Association between biotic and abiotic parameters and the occurrence of Cyanobacteria in a Brazilian reservoir. Environmental Monitoring and Assessment 184: 4635-4645.

Groppo JD, Lins SRM, Camargo PB, et al. 2015. Changes in soil carbon, nitrogen and phosphorus due to land-use changes in Brazil. Biogeosciences 12: 4765-4780.

Hammer Ø, Harper DAT, Ryan PD. 2001. Past: Paleontological statistics software package for education and data analysis. Palaeontologia Electronica 4: 1-9

Henry R, Barbosa FAR. 1989. Thermal structure, heat content and stability of two lakes in the National Park of Rio Doce Valley (Minas Gerais, Brazil). Hydrobiologia 171: 189-199.

Herrero A, Muro-Pastor AM, Flores E. 2001. Nitrogen control in cyanobacteria. Journal of Bacteriology 183:411-425.

Huertas IE, Rouco M, López-Rodas V, Costas E. 2011. Warming will affect phytoplankton differentially: evidence through a mechanistic approach. Proceedings of the Royal Society B In press 278: 3534-3543.

Huszar VLM, Caraco NF, Roland F, Cole J. 2006. Nutrient-chlorophyll relationships in tropical-subtropical lakes: do temperate models fit? Biogeochemistry 79: 239-250.
Kokocinski M, Soininen J. 2012. Environmental factors related to the occurrence of Cylindrospermopsis raciborskii (Nostocales, Cyanophyta) at the north-eastern limit of its geographical range. European Journal of Phycology 47: 12-21.

Lagos N, Onodera H, Zagatto PA, Andrinolo D, Azevedo SMFQ, Oshima Y. 1999. The first evidence of paralytic shellfish toxins in the freshwater cyanobacterium Cylindrospermopsis raciborskii, isolated from Brazil. Toxicon 37: 1359-1373.

Lamparelli MC. 2004. Grau de trofia em corpos d'água do estado de São Paulo: avaliação dos métodos de monitoramento. PhD Thesis, Universidade de São Paulo, Brazil.

Latini A, Petrere M. 2004. Reduction of a native fish fauna by alien species: an example from Brazilian freshwater tropical lakes. Fisheries Management and Ecology 11: 71-79.

Marotta H, Fontes MLS, Petrucio MM. 2012. Natural events of anoxia and low respiration index in oligotrophic lakes of the Atlantic Tropical Forest. Biogeosciences 9: 2879-2887.

McGregor GB, Fabbro LD. 2000. Dominance of Cylindrospermopsis raciborskii (Nostocales, Cyanoprokaryota) in Queensland tropical and subtropical reservoirs: implications for monitoring and management. Lakes \&Reservoirs: Research \& Management 5: 195-205.

Mischke U. 2003 Cyanobacteria associations in shallow polytrophic lakes: influence of environmental factors. Acta Oecologica 24: 11-23.

Morris DP, Lewis WM Jr. 1988. Phytoplankton nutrient limitation in Colorado mountain lakes. Freshwater Biology19: 315-327.

Myers N, Mittermeier RA, Mittermeier CG, Fonseca GAB, Kent J. 2000. Biodiversity hotspots for conservation priorities. Nature 403: 853-858.

Neilan BA, Saker ML, Fastner J, Törökné A, Burns BP. 2003. Phylogeography of the invasive cyanobacterium Cylindrospermopsis raciborskii. Molecular Ecology 23: 133-140.

OECD - Organization for Economic Cooperation and Development. 1982. Eutrophication of water: monitoring, assessment and control. Paris, OECD.

Padisák J. 1997.Cylindrospermopsis raciborskii (Woloszynska) Seenaya and Subba Raju, an expanding, highly adaptive cyanobacterium: worldwide distribution and review of ecology. Archive für Hydrobiologie 107: 563-593.

Piccini C, Aubriot L, Fabre A, et al. 2011. Genetic and eco-physiological differences of South American Cylindrospermopsis raciborskii isolates support the hypothesis of multiple ecotypes. Harmful Algae 10: 644-653.

Ramsar. 2010. The Ramsar List of wetlands of international importance. http://www.ramsar.org/pdf/sitelist_order.pdf. 15 Feb. 2015.

Ranta P, Blom T, Niemelä J, Joensuu E, Siitonen M. 1998. The fragmented Atlantic rain forest of Brazil: size, shape and distribution of forest fragments. Biodiversity and Conservation 7: 385-403.

Read JS, Rose KC. 2013. Physical responses of small temperate lakes to variation in dissolved organic carbon concentrations. Limnology and Oceanography 58: 921-931.

Ribeiro MC, Metzgera JP, Martensena AC, Ponzonib FJ, Hirota MM. 2009.The Brazilian Atlantic Forest: How much is left, and how is the remaining forest distributed? Implications for conservation. Biological Conservation 142: 1141-1153.

Rückert G, Giani A. 2004. Effect of nitrate and ammonium on the growth and protein concentration of Microcystis viridis Lemmermann (Cyanobacteria). Revista Brasileira de Botânica 27: 325-331.

Scheffer M, Rinaldi S, Gragnani A, Mur LR, Nes EH. 1997. On the dominance of filamentous cyanobacteria in shallow, turbid lakes. Ecology 78: 277-282.

Smith VH. 1983. Low nitrogen to phosphorus ratios favor dominance by blue-green algae in lake phytoplankton. Science 221: 669-671.

Smith VH. 2003. Eutrophication of freshwater and coastal marine ecosystems: a global problem. Environmental Science and Pollution Research 10: 126-139.

Soares MCS, Lürling M, Huszar VLM. 2013. Growth and temperaturerelated phenotypic plasticity in the cyanobacterium Cylindrospermopsis raciborskii. Phycological Research 61: 61-67.

Souza MBG, Barros CFA, Barbosa, F, Hajnal E, Padisák J. 2008. Role of atelomixis in replacement of phytoplankton assemblages in Dom Helvécio Lake, South-East Brazil. Hydrobiologia 607: 211-224. 
The necessity of management in a lake of the Atlantic Forest biodiversity hotspot:

nitrogen levels connected to a persistent bloom of Cylindrospermopsis raciborskii

Sterner RW. 2008. On the phosphorus limitation paradigm for lakes. International Review of Hydrobiology 93: 433-45.

Sun J, Liu D. 2003. Geometric models for calculating cell biovolume and surface area for phytoplankton. Journal of Plankton Research 25: 1331-1346.

Tavares VC, Perini FA, Lombardi JA. 2007. The bat communities (Chiroptera) of the Parque Estadual do Rio Doce, a large remnant of Atlantic Forest in southeastern Brazil. Lundiana 8: 35-47

Tundisi JG. 1997. A note on the effect of rainfall in the process of stratification and stability in the rio doce lakes. In: Tundisi JG, Saijo Y. (eds.) Limnological studies on the Rio Doce Valley lakes, Brazil. São Carlos, Brazilian Academy of Sciences. p. 79- 82

Utermöhl H. 1958. Zur Vervollkomnung der quantitativen PhytoplanktonMethodik. Mitteilung Internationale Vereinigung fuer Theoretische unde Amgewandte Limnologie 9: 1-38.

Veloso LM, Melo CCLS, Oliveira VS, Rückert, G. 2011. Lagoa Marola: Análise dos padrões de balneabilidade e de cianobactérias de acordo com a legislação vigente. In: Anais da $13^{a}$ Semana de Iniciação Científica e $4^{\text {a }}$ Semana de Extensão -Unileste MG: Ciência para o desenvolvimento regional. http://www.unilestemg.br/pic/sic-13/ resumos/pesquisa-engenharia-tecnologia/lagoa-marola-analise-dospadroes-de-balneabilidade.pdf. 10 Jul. 2015.

Vinebrooke RD, Cottingham KL, Norberg J, et al. 2004. Impacts of multiple stressors on biodiversity and ecosystem functioning: the role of species co-tolerance. Oikos 104: 451-457.

Wagner C, Adrian R. 2009. Cyanobacteria dominance: Quantifying the effects of climate change. Limnology and Oceanography 58: 2460-2468.

Watson SB, McCauley E, Downing JA. 1997. Patterns in phytoplankton taxonomic composition across temperate lakes of differing nutrient status. Limnology and Oceanography 42: 487-495.

Xu H, Paerl HW, Qin B, Zhu G, Gao G. 2010. Nitrogen and phosphorus inputs control phytoplankton growth in eutrophic Lake Taihu, China. Limnology and Oceanography 55:420-432.

Yang X, Wu X, Hao H, He Z. 2008. Mechanisms and assessment of water eutrophication. Journal of Zhejiang University - Science B. 9: 197-209.

Yoshida CE, Uieda VS. 2014. The importance of a Biosphere Reserve of Atlantic Forest for the conservation of stream fauna. Brazilian Journal of Biology 74: 382-394. 